\title{
ПАТОМОРФОЛОГИЧЕСКИЕ ИЗМЕНЕНИЯ ПОЧЕК У КОШЕК
}

\section{T.I. Vakhrusheva}

\section{PATHOMORPHOLOGICAL CHANGES OF KIDNEYS IN CATS}

Вахрушева Т.И. - канд. ветеринар. наук, доц. каф. анатомии, патологической анатомии и хирургии Красноярского государственного аграрного университета, г. Красноярск.

E-mail: vlad_77.07@mail.ru

Изучена патоморфологическая картина изменений почек у кошек различных пород и возрастных групп с установлением патогномоничных морфологических признаков. Объектом исследования являлись124 трупа кошек в возрасте от 3 месяцев до 16 лет (пол животных - 61 самка, 63 самиа), из которых 5 трупов - породы мейн-кун, 21 - персидской породы, 32 - британской, 7 - шотладской вислоухой породы, 59 - метисы. Смерть 74 животных наступила в результате эфртаназии, у 50 животных наблюдалась патологическая ненасильственная смерть. Инфрекция была исключена во всех случаях прижизненными лабораторными исследованиями. Во время вскрытия проводился забор материала для гистологического исследования - фррагменты тканей почек. Патолого-анатомический материал фриксировался в 10 \% нейтральном растворе формалина, срезы изготавливались на микротоме "Техном МЗП-01», окрашивались гематоксилином Эрлиха и эозином. Микрофотосъемку и анализ микрофотографий проводили на фomoannapame Canon EOS 1100D. Результаты патоморфологического изучения почек показали, что патологические изменения почек различного характера обнаруживались в 92,7 \% случаев патолого-анатомического вскрытия, при этом в 58,1 \% случаев выявлялись воспалительные процессы - нефррит, пиелонефрит, гломерулонефрит, также у животных в возрасте старше 4 лет в 23 \% случаев наблюдалась тенденция перехода острой формы воспаления в подострую или хроническую, следствием чего являлось развитие у кошек в возрасте 3-7 лет фиброза и умеренно выраженного нефросклероза, а у кошек в воз-
Vakhrusheva T.I. - Cand. Veterinary Sci., Assoc. Prof., Chair of Anatomy, Pathological Anatomy and Surgery, Krasnoyarsk State Agrarian University, Krasnoyarsk.

E-mail: vlad_77.07@mail.ru

расте 5-12 лет - выраженного нефросклероза. У животных в возрасте 7-10 лет наряду с нефросклерозом наблюдались признаки гиалиноза и амилоидоза, связанные с хронической аутоинтоксикацией на фроне почечной и полиорганной недостаточности. Патоморфологическая картина двустороннего поликистоза обнаруживалась в 100 \% случаев вскрытия трупов кошек персидской породы, а также у 40,6 и 28,5 \% кошек британской и шотландской вислоухой породы соответственно, что подтверждает данные о породной предрасположенности.

Ключевые слова: мочевыделительная система, патоморфологические изменения, нефрит, гломерулонефрит, амилоидоз, нефросклероз, поликистоз, домашняя кошка.

Pathomorphological picture of kidney changes in cats of various breeds and age groups was studied with the establishment of pathognomonic morphological characters. The objects of the study were 124 corpses of cats aged from 3 months to 16 years (the sex of animals - 61 females, 63 males), of which 5 corpses were Maine Coon, 21 were Persian, 32 were British, 7 were Scottish fold, 59 mestizos. The death of 74 animals occurred as a result of ephtanasia, in 50 animals pathological nonviolent death was observed. The infection was excluded in all the cases by intravital laboratory tests. During the autopsy, the material was taken for histological examination - the fragments of kidney tissue. Pathological material was fixed in $10 \%$ neutral formalin solution; the sections were made on Tekhnom MZP-01 microtome, stained with Ehrlich hematoxylin. Microphotography and microphotos analysis were performed by a Canon 
EOS 1100D camera. The results of pathomorphological study of the kidneys showed that pathological changes in the kidneys of different nature were detected in $92.7 \%$ of cases of postmortem autopsy, while in $58.1 \%$ of cases inflammatory processes of infectious - nephritis, pyelonephritis and infectious-allergic - glomerulonephritis etiology were also detected, also in animals over 4 years of age, in $23 \%$ of cases there was a tendency for the acute form of inflammation to become subacute or chronic, resulting in the development of fibrosis and in cats aged 3-7 years of moderately expressed nephrosclerosis and cats aged 5-12 years - expressed nephrosclerosis. In animals aged 7-10 years, along with nephrosclerosis, signs of hyalinosis and amyloidosis associated with chronic auto-toxicity were observed along with renal and multiple organ failure. Pathomorphological picture of bilateral polycystosis was found in $100 \%$ of autopsy of the corpses of cats of Persian breed, as well as in $40.6 \%$ and $28.5 \%$ of British and Scottish fold cats, respectively, that confirms the data on the breed predisposition.

Keywords: urinary system, pathological changes, nephritis, glomerulonephritis, amyloidosis, nephrosclerosis, polycystic, domestic cat.

Введение. Мочевыделительная система домашних кошек является крайне уязвимой в связи с ее анатомо-физиологическими особенностями, в результате чего в тканях органов в процессе жизни животного часто развиваются различные патологические процессы, чему также способствуют нарушения кормления и содержания, отсутствие профилактики, своевременной диагностики и лечения, что, в свою очередь, ведет к развитию глубоких, необратимых дегенеративно-некротических процессов, в частности, в тканях почек, сопровождающиеся выраженным нарушением их функции. Согласно ветеринарной статистике, на долю патологий почек и мочевыводящих путей у домашних кошек приходится более 33 \% от всех заболеваний незаразной природы [1]. Частота врожденных заболеваний почек, таких как поликистоз, на данный момент еще полностью не охарактеризована [2]. Однако многими исследователями в последние годы выявлена тенденция учащения случаев возникновения патологий с генетической детерминацией, сопровождающихся дефектным гистогенезом тканей органа, при этом отмечается, что развитие данной патологии также может быть обусловлено породной предрасположенностью [3-6].

Патологические процессы, развивающиеся в почках, на ранних стадиях часто не имеют выраженных симптомов или же характеризуются стертой клинической картиной и латентным хроническим течением, в результате чего вовремя не диагностируются и обуславливают развитие почечной недостаточности различной степени выраженности [3-9]. В связи с высоким уровнем заболеваемости кошек патологиями органов мочевыделительной системы изучение патоморфологической картины изменений почек является актуальной темой.

Цель исследований: проведение анализа картины патоморфологических изменений почек у домашних кошек различных возрастных групп и пород с установлением наиболее часто встречающихся у данного биологического вида животных патологий и патогномоничных для них морфрологических признаков.

Материалы и методы исследований. В течение 2016-2019 гг. было проведено патологоанатомическое вскрытие 124 трупов кошек в возрасте от 3 месяцев до 16 лет (пол животных - 61 самка, 63 самца), из которых 5 трупов - породы мейн-кун, 21 - персидской породы, 32 - британской, 7 - шотладской вислоухой породы, 59 - метисы. Смерть 74 животных наступила в результате эфтаназии, у 50 животных наблюдалась патологическая ненасильственная смерть. Инфекция была исключена во всех случаях прижизненными лабораторными исследованиями.

Во время вскрытия проводился забор материала для гистологического исследования фрагменты тканей почек. Патолого-анатомический материал фиксировался в $10 \%$ нейтральном растворе формалина, срезы изготавливались на микротоме «Техном МЗП-01», окрашивались гематоксилином Эрлиха и эозином, микроскопия проводилась на микроскопе «Levenhuk 320». Микрофотосъемку и анализ микрофотографий проводили на фотоаппарате Canon EOS 1100D.

Результаты исследований. При проведении патоморфологических исследований были получены следующие результаты: при вскрытии 115 трупов кошек $(92,7$ \%) были обнаружены патолого-анатомические изменения почек различного характера и интенсивности проявления.

Воспалительные процессы ткани почек различной остроты течения регистрировались при 
вскрытии трупов животных всех возрастов и пород, при этом чаще всего обнаруживались признаки острого нефрита, пиелонефрита и гломерулонесрита - у 72 кошек $(58,1 \%$ от общего количества случаев вскрытия), который в основном имел серозный характер, у кошек в возрасте 1-2 лет - 10 случаев (8,1\%), в возрасте 2-3 лет - 24 случая (19,35\%), в возрасте 3-4 лет - 25 случаев (20,16 \%), в возрасте 4-7 лет 13 случаев (10,48 \%). В почках отмечались следующие патоморфологические изменения: увеличение органов в размерах, воспалительный отек, повышенное кровенаполнение сосудов, неоднородность окраски с поверхности и на разрезе - характерный «крапчатый рисунок», особенно выраженный при гломерулонефрите, соответствующий локализации переполненных кровью сосудов и клубочков почечных телец, на разрезе наблюдалось расширение и отек коры, сглаженность границы между корой и медуллярной зоной, резкое кровенаполнение юкстамедуллярной зоны, повышенная влажность паренхимы органа (рис. 1, 2).

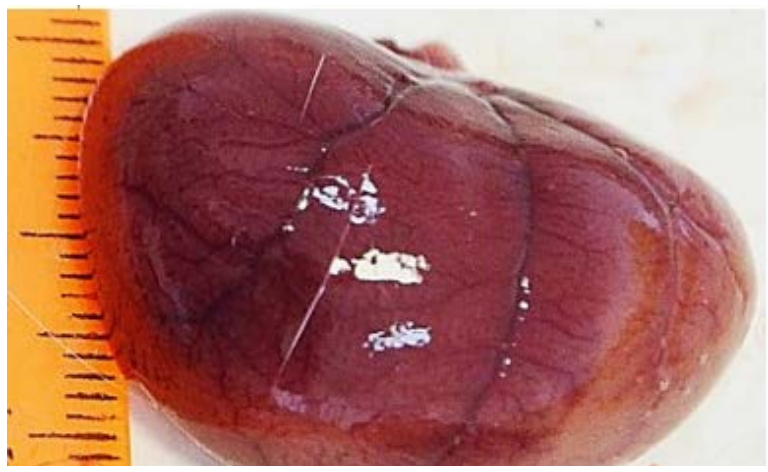

Puс. 1. Острый серозный гломелуронефрит у кошки (британская порода) - увеличение размеров органа, воспалительная гиперемия, характерный крапчатьй рисунок

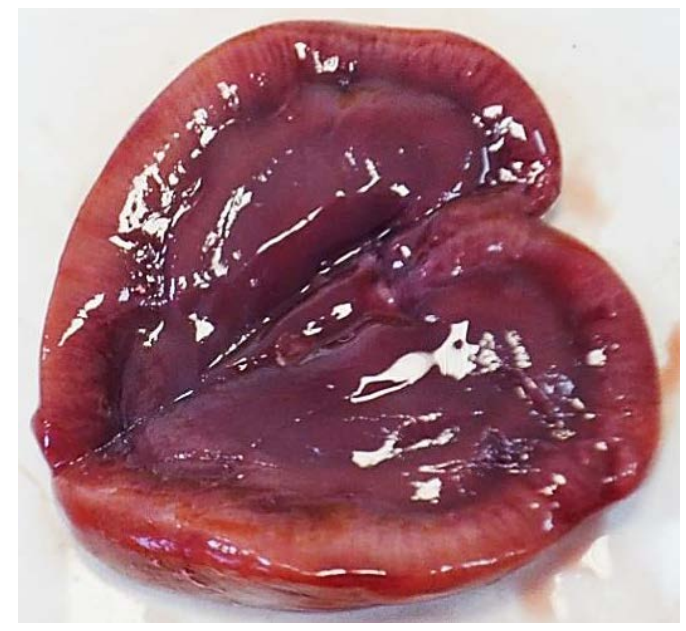

Puc. 2. Острый серозный гломерулонефрит у кошки (британская порода) - крапчатьй рисунок коры, острая воспалительная гиперемия юкстамедуллярной зоны

Гистологические изменения характеризовались острым воспалительным диффузным венозно-капиллярным полнокровием сосудов интерстиция и капиллярных петель клубочков с эритростазами, выраженным диффузным отеком межуточной ткани, скоплением в полости капсул Боумена-Шумлянского серозного экссу- дата (бледно-розовых гомогенных масс), белковой дистрофией и некробиотическими процессами эпителия канальцев, пикнозом и лизисом их ядер, скоплением в полости канальцев белковых цилиндров и десквамированных эпителиальных клеток (рис. 3, 4). 


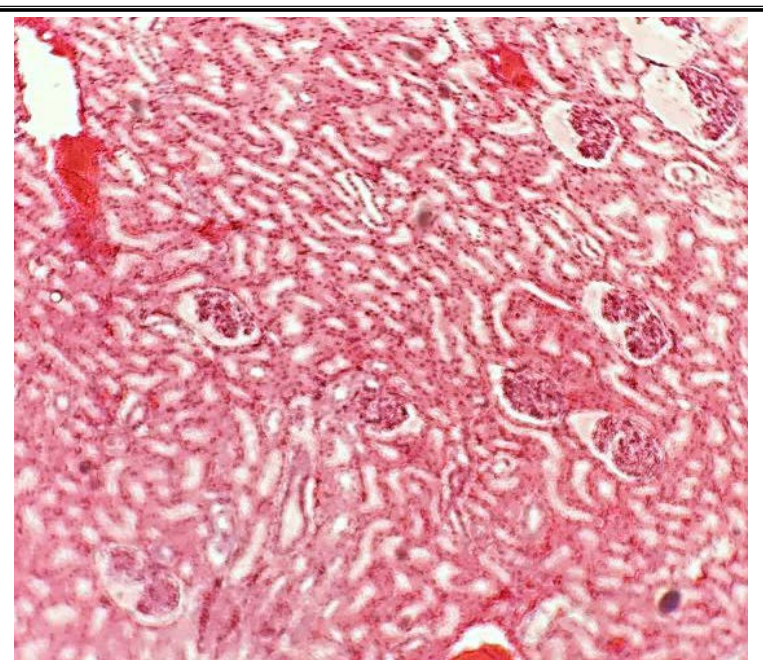

Puс. 3. Острый серозный гломерулонефрит у кошки (британская порода) - серозный отек стромы, резкое кровенаполнение сосудов, эритростазы, лапчатость сосудистых клубочков (окраска гематоксилином и эозином; ×100)

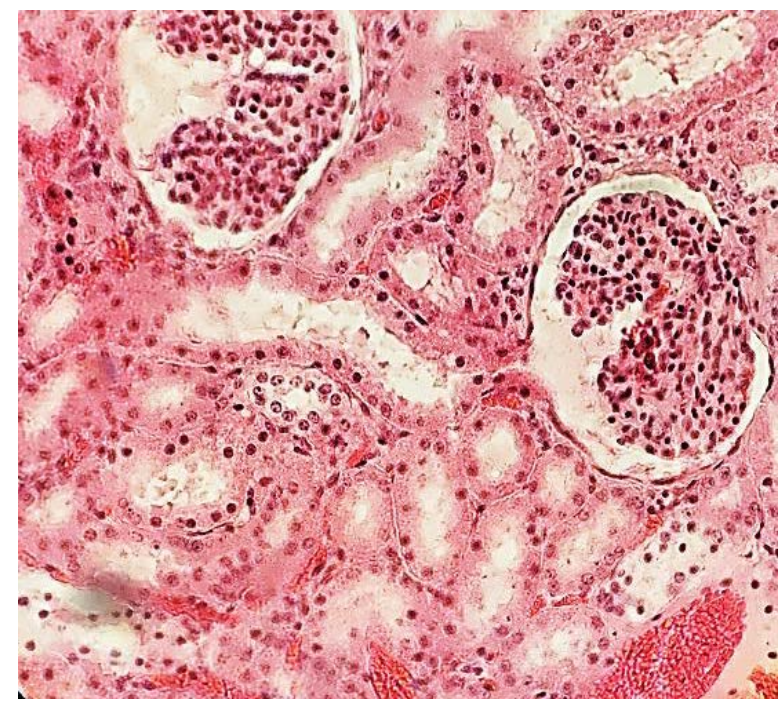

Puc. 4. Острый гломерулонефрит у кошки (британская порода) - скопление серозного экссудата в полости капсулы почечных телец, белковая дистрофиия и некроз клеток эпителия канальцев (окраска гематоксилином и эозином; ×100)

Подострые и хронические воспалительные процессы в основном обнаруживались у животных в возрасте старше 4 лет, подобная картина выявлялась при вскрытии 36 трупов кошек всех пород $(23,03 \%)$. Хроническое воспаление сопровождалось изменениями органов, характерными для начальных признаков фиброза - уплотнением органов, умеренной очаговой гиперемией и выраженным крапчатым рисунком поверхности и на разрезе, неравномерностью окраски коры - на серо-красном фоне очажки красного цвета (рис. 5). При гистологическом исследовании выявлялись очаги тубулорексиca, признаки атрофии эпителия канальцев с резким его истончением, вплоть до нитевидного, наличием в полости гомогенных розовых коллоидоподобных масс и характерная «лапчатость» клубочков с умеренным склерозом их капсулы и стенок сосудов, а также наличие очагов продуктивного воспаления и пролифрерации стромы (рис. 6). 


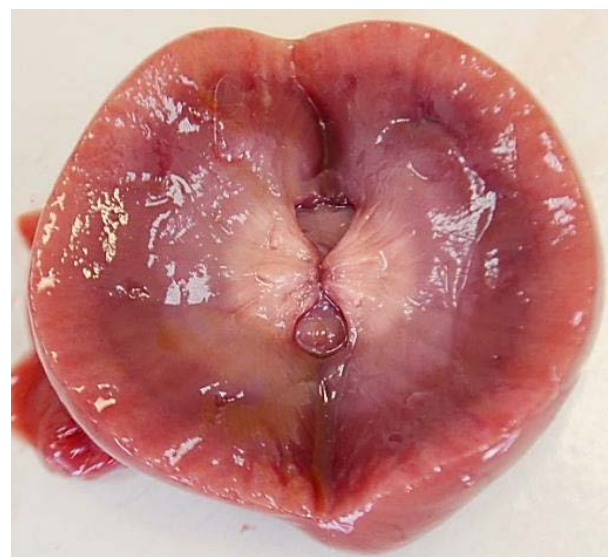

Puc. 5. Подострый нефрит у кошки (порода мейн-кун) - крапчатый рисунок, умеренная гиперемия коры и медуллярной зоны

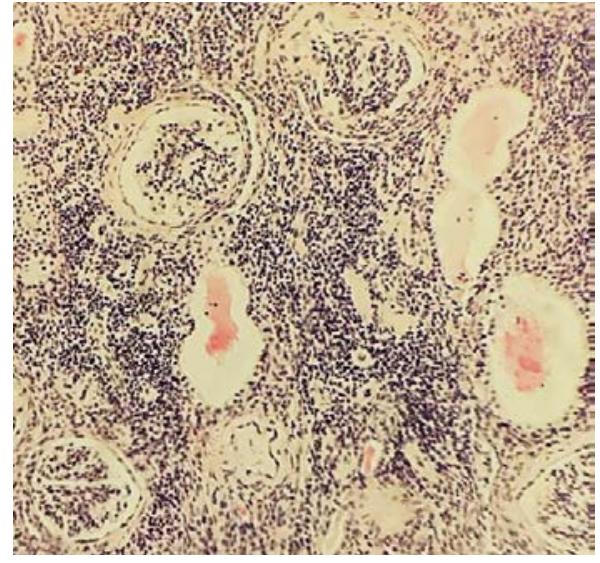

Рис. 6. Хронический нефрит у кошки (метис) - лимфоидные инфильтраты в строме, атрофиия эпителия канальцев (окраска гематоксилином и эозином; х400)

Признаки умеренно выраженного нефрроск- ной бугристости поверхности, при этом органы лероза отмечались при вскрытии трупов живот- имели неравномерную бледную серо-красную ных в возрасте 3-7 лет и характеризовались окраску вследствие разрастания соединительзначительным уплотнением ткани почек без вы- ной ткани (рис. 7, 8). раженного уменьшения их объема и характер-

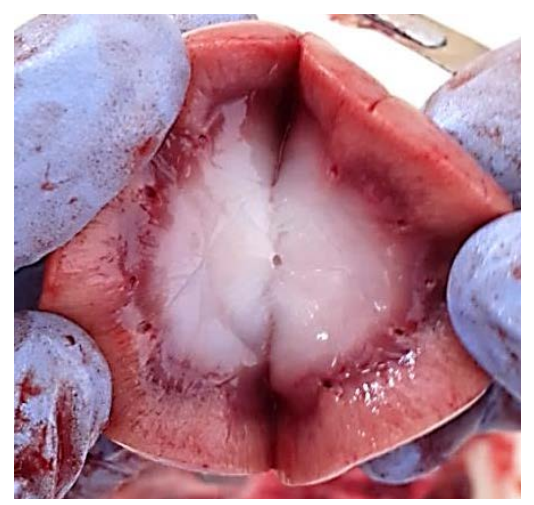

Puc. 7. Начальная стадия нефросклероза у кошки (шотландская вислоухая) выраженный фриброз мозгового вещества 


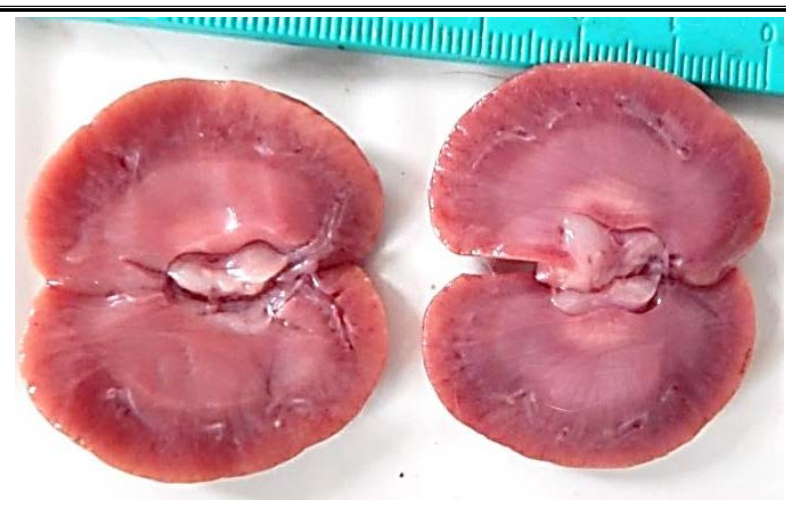

Puc. 8. Начальная стадия нефросклероза у кошки (британская порода) - умеренное увеличение, уплотнение консистенции, бледный, серо-красный цвет органов

Признаки выраженного нефросклероза были обнаружены у $21(35,59 \%)$ кошек-метисов, 10 $(31,25 \%)$ британцев, 2 (40,00 \%) мейн-кунов. Причем характерная патоморфологическая картина отмечалась у животных в возрасте 5-12 лет. Патолого-анатомические изменения были следующими: органы уменьшены в объеме, деформированы, значительно уплотнены, поверхность - мелко-зернистая или грубобугристая, окраска - неравномерная, бледная, на разрезе граница между корой и мозговым веществом - стертая, мозговое вещество бледно-серого цвета, в коре и медуллярной зоне выявлялись мелкие кистозные полости с прозрачным содержимым (рис. 9). В 40 \% случаев признаки нефросклероза сочетались с картиной рецидивирующего острого воспаления ткани почек, которые чаще всего развиваются на фоне аутоинтоксикации организма при азотемии, вследствие выраженной почечной недостаточности (рис. 10).

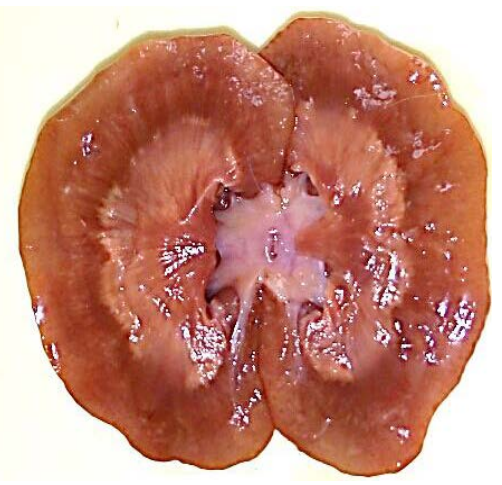

Puс. 9. Нефрросклероз у кошки (метис): уменьшение в размерах, дефоормация, бледньй цвет органа

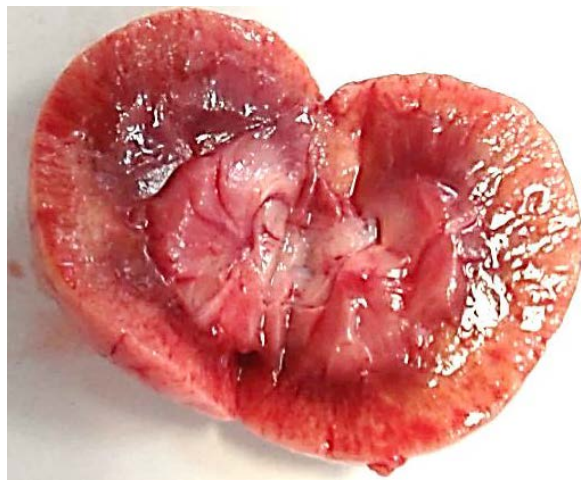

Puc. 10. Нефросклероз у кошки (метис) с признаками острого воспаления 
Гистологически в ткани измененных органов выявлялась картина хронического гломерулонефрита, характеризующегося сращением капиллярных петель клубочков с их капсулой, перигломерулярным склерозом, расширением полости канальцев с выраженной атрофией их эпителия - «щитовидная почка». Также выявлялось утолщение стенок артерий за счет склероза, гиалиноз артериол, в некоторых случаях обнаруживались признаки амилоидоза, характеризующиеся отложением масс амилоида не только в стенках артериол сосудистых клубоч- ков, но и в базальной мембране канальцев, чаще проксимальных и в стенках сосудов почек (рис. 11, 12). В случае сочетания признаков несросклероза с острым воспалением ткани органа выявлялось выраженное очаговое венозно-капиллярное полнокровие мозгового слоя, отек интерстиция, кровенаполнение групп капиллярных петель клубочков и наличие в просветах ряда капсул Боумена-Шумлянского незначительного и умеренного количества слабозернистых бледно-розовых масс.

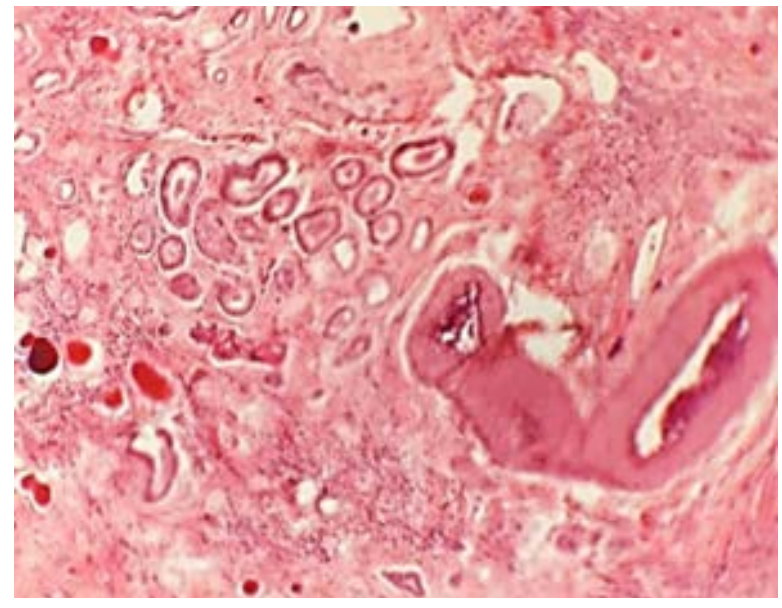

Puc. 11. Нефрросклероз у кошки (метис) - разрастание соединительной ткани стромы, деформация и растяжение канальцев, склероз и гиалиноз стенок сосудов (окраска гематоксилином и эозином; ×100)

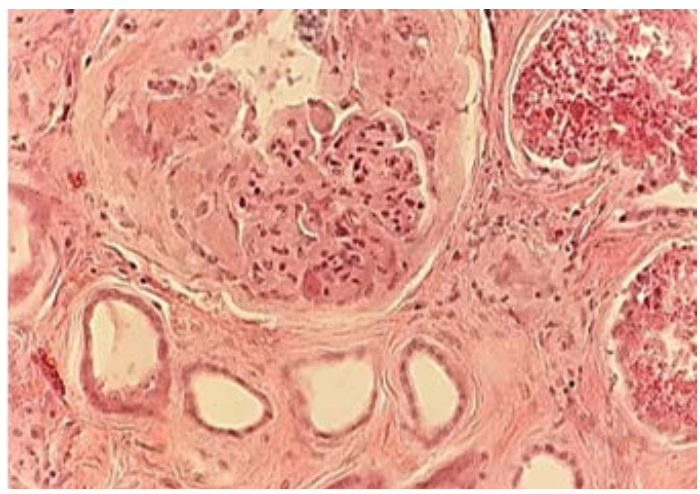

Puc. 12. Нефрросклероз у кошки (метис) - атроффия эпителия канальцев, цилиндры в просвете канальцев, склероз и гиалиноз капсулы клубочков (окраска гематоксилином и эозином; х400)

При вскрытии 15 трупов (100 \%) кошек персидской породы, 13 трупов кошек британской породы (40,6 \%), 2 трупов кошек породы шотландская вислоухая (28,5 \%), 9 трупов метисов $(10,15 \%)$ в почках была обнаружена картина двустороннего поликистоза различной степени выраженности, характеризующаяся локализацией в коре и мозговом веществе ткани обоих органов множественных тонкостенных полостей неправильной округлой формы, заполненных 
бесцветной, желтоватой прозрачной или мутноватой жидкостью (рис. 13). В некоторых случаях кистозные полости достигали 10-12 см в размерах, при этом наиболее значительные изменения выявлялись у трупов кошек персидской породы в возрасте 6-8 лет, у более молодых животных этой породы - в возрасте от 1 до 4 лет, а также у трупов кошек британской породы и метисов кистозные полости чаще были единичными, имели размеры 1,5-1,8 см, локализовались преимущественно в коре. Гистологически в ткани органов выявлялись множественные полости различных размеров, представляющие собой почечные канальцы со значительно расширенными, десрормированными просветами и истонченным эпителием, а также выраженный фиброз интерстиция, сдавливание и атрофия тканевых элементов (рис. 14). Установлено, что поликистоз почек является наследственной патологией британских и персидских кошек, имеет аутосомно-доминантный характер и связан с породной предрасположенностью, прогрессируя у животных в возрасте старше 4 лет, что также подтверждается данными исследования [1].

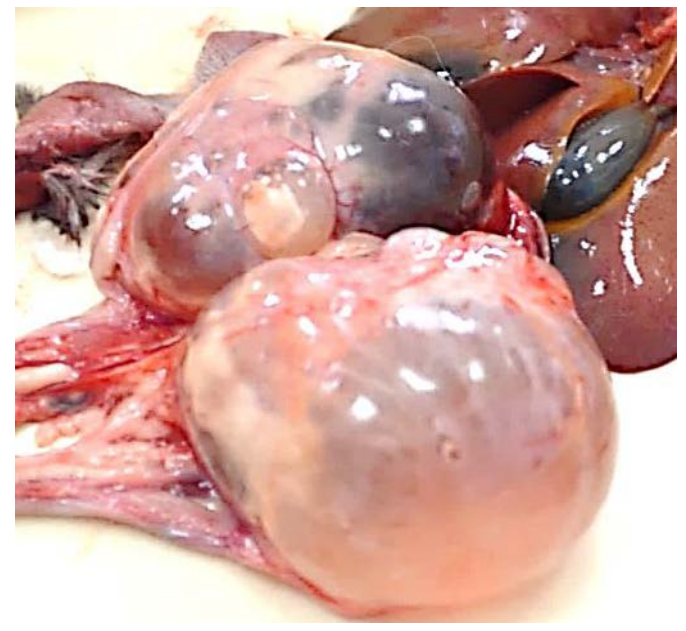

Puс. 13. Поликистоз почек персидской кошки: наличие множественных полостей размером от 3 до 12 см в диаметре

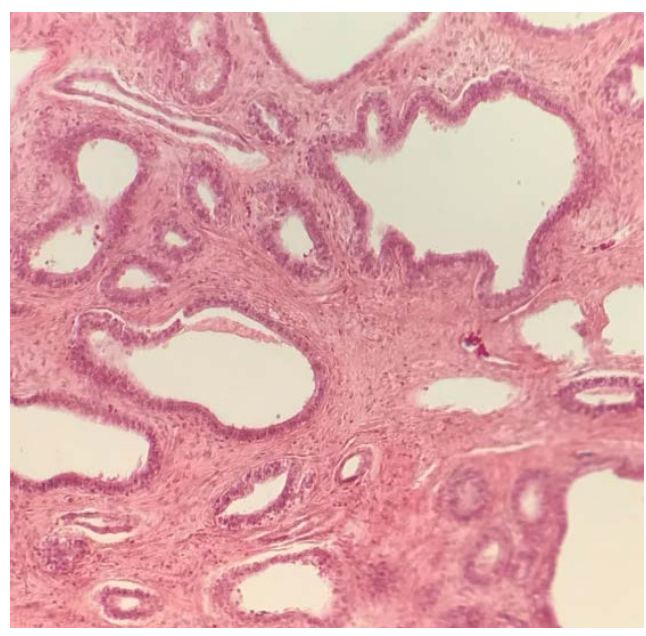

Puс. 14. Поликистоз почек: расширение и дефрормация канальцев, фриброз интерстиция (окраска гематоксилином и эозином; ×100) 
В трех случаях вскрытия (2,4 \%) у трупов кошек в возрасте 7, 9 и 10 лет были обнаружены выраженные признаки амилоидоза, патоморфологически характеризующиеся картиной «большой белой почки» - органы увеличены в размерах, бледной, серо-белой или серожелтой окраски, поверхность разреза «саль- ная», полупросвечивающаяся, консистенция мягкая (рис. 15). Гистологически в клубочках сосудистых телец, собственной оболочке канальцев, между канальцами в межуточной соединительной ткани, в стенках сосудов выявлялись гомогенные массы амилоида, окрашивающиеся в бледно-розовый цвет (рис. 16).

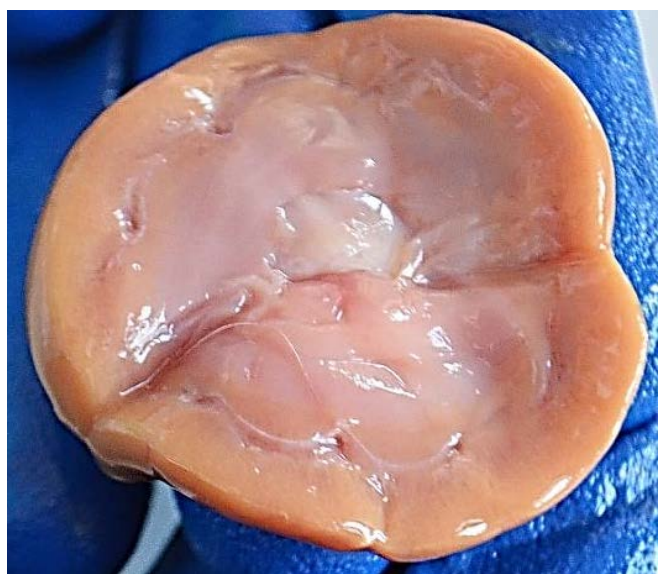

Puс. 15. Амилоидная нефропатия (метис) - «большая белая почка», орган увеличен в объеме, окрашен в бело-желтый цвет, граница между корой и мозговым веществом стерта

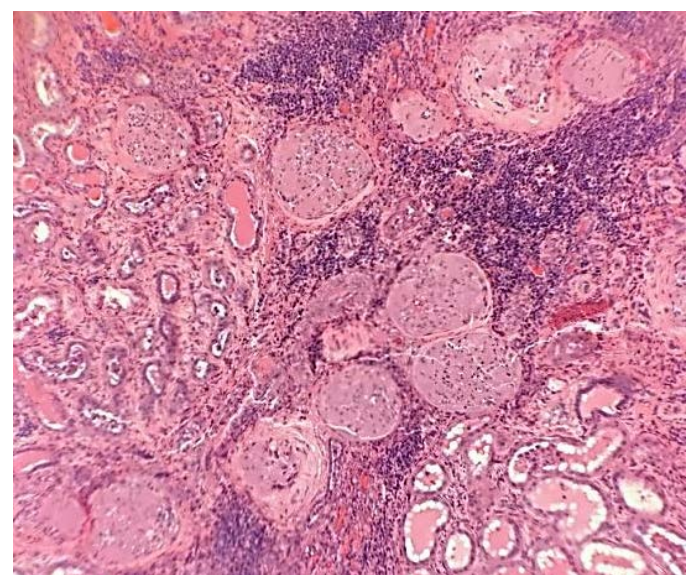

Puc. 16. Амилоидная нефрропатия (метис) - отложение амилоида между сосудистьми петлями клубочков почки (окраска гематоксилином и эозином; ×100)

Выводы. Патоморфологические изменения почек различного характера обнаруживались в $92,7 \%$ случаев вскрытия трупов кошек, при этом чаще всего наблюдались воспалительные процессы инфекционной (нефрит, пиелонефрит) и инфекционно-аллергической (гломерулонефрит) этиологии - 58,1 \%, из которых большее количество наблюдалось у животных в возрасте от 1 года до 4 лет, при этом у кошек в возрасте старше 4 лет в более чем 23 \% случаев выявлялись признаки перехода острых вос- палительных процессов в подострую или хроническую форму, породная предрасположенность не выявлена. Следствием хронического воспаления ткани почек является развитие фиброза и умеренного нефросклероза, наблюдающегося у животных в возрасте 3-7 лет, признаки выраженного нефросклероза чаще наблюдались у кошек старшего возраста - 5-12 лет. У животных в возрасте 7-10 лет также, наряду с выраженным нефросклерозом, обнаруживались глубокие дегенеративные процессы 
ткани почек - гиалиноз и, в некоторых случаях, амилоидоз, связанные с хронической аутоинтоксикацией, в том числе с нарастающей уремией на фоне почечной и полиорганной недостаточности. Патоморфологическая картина двустороннего поликистоза различной степени выраженности обнаруживалась у кошек персидской породы - в 100 \% случаев вскрытия, у кошек британской и шотландской вислоухой породы этот показатель был ниже - 40,6 и 28,5 \% соответственно, подтверждая данные 0 породной предрасположенности животных к данной патологии почек.

\section{Литература}

1. Слесаренко Н.А., Кайдановская Н.А. Особенности строения почек новорожденных котят по данным ультразвукового и морфологического исследований // Российский ветеринарный журнал. - 2006. - № 2. C. 22-25.

2. Рей С.М. Наследственные и врожденные заболевания почек у кошек // Veterinary Focus. - 2013. - № 23 (3). - C. 10-16.

3. Эллиот Дж., Гроер Г. Нефрология и урология собак и кошек. - М.: Аквариум-Принт, 2014. - 352 c.

4. Фарафонттова В.С. Лечение хронической почечной недостаточности у собак и кошек: дис. ... канд. ветеринар. наук. - СПб., 2011. $144 \mathrm{c}$.

5. Кайдановская Н.А. Морфосонографические корреляты почек у кошек в норме и при патологии: автореф. дис. ... канд. биол. наук / Москов. гос. акад. ветеринар. медицины и биотехнологии им. К.И. Скрябина. - М., 2009. $-20 \mathrm{c}$.

6. Осипова Ю.С. Распространение заболеваний мочевыделительной системы кошек в регионе Кавказские Минеральные Воды // Вестн. АПК Ставрополья. - 2015. - № 2. C. 109-115.

7. Швейехаузер А., Франсе Т. Распространение болезней почек у кошек // Veterinary Focus. - 2008. - № 18 (2). - C. 2-7.

8. Walker A.D., Weaver A.D., Anderson R.S. et al. An epidemiological survey of the feline urological syndrome // Journal of Small Animal Practice. - 1977. - № 18. - P. 283-301.

9. Виноградова О.Ю. Клинико-морфологические изменения при хронической почечной недостаточности кошек и методы коррекции: автореф. дис. ... канд. ветеринар. наук / Саратов. гос. аграр. ун-т им. Н.И. Вавилова. - Саратов, 2012. - 23 с.

\section{Literatura}

1. Slesarenko N.A., Kajdanovskaya N.A. Osobennosti stroeniya pochek novorozhdennyh kotyat po dannym ul'trazvukovogo i morfologicheskogo issledovanij // Rossijskij veterinarnyj zhurnal. - 2006. - № 2. - S. 22-25.

2. Rej S.M. Nasledstvennye i vrozhdennye zabolevaniya pochek u koshek // Veterinary Focus. - 2013. - № 23 (3). - C. 10-16.

3. Elliot Dzh., Groer G. Nefrologiya i urologiya sobak i koshek. - M.: Akvarium-Print, 2014. $352 \mathrm{~s}$.

4. Farafontova V.S. Lechenie hronicheskoj pochechnoj nedostatochnosti u sobak i koshek: dis. ... kand. veterinar. nauk. - SPb., 2011. - $144 \mathrm{~s}$.

5. Kajdanovskaya N.A. Morfosonograficheskie korrelyaty pochek $\mathrm{u}$ koshek $\mathrm{v}$ norme i pri patologii: avtoref. dis. ... kand. biol. nauk / Moskov. gos. akad. veterinar. mediciny i biotekhnologii im. K.I. Skryabina. - M., 2009. $20 \mathrm{~s}$.

6. Osipova YU.S. Rasprostranenie zabolevanij mochevydelitel'noj sistemy koshek $v$ regione Kavkazskie Mineral'nye Vody // Vestn. APK Stavropol'ya. - 2015. - № 2. - S. 109-115.

7. SHvejghauzer A., Franse T. Rasprostranenie boleznej pochek u koshek // Veterinary FoCus. - 2008. - № 18 (2). - S. 2-7.

8. Walker A.D., Weaver A.D., Anderson R.S. et al. An epidemiological survey of the feline urological syndrome // Journal of Small Animal Practice. - 1977. - № 18. - P. 283-301.

9. Vinogradova O.YU. Kliniko-morfologicheskie izmeneniya pri hronicheskoj pochechnoj nedostatochnosti koshek i metody korrekcii: avtoref. dis. ... kand. veterinar. nauk / Saratov. gos. agrar. un-t im. N.I. Vavilova. - Saratov, 2012. $-23 \mathrm{~s}$. 